\title{
癌化学療法に対する注射処方監査支援システムの構築と運用
}

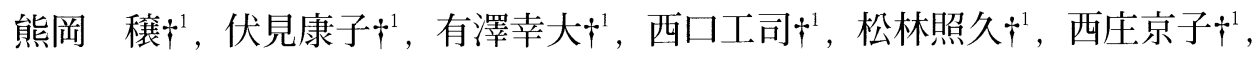 \\ 栄田敏之 $\dagger^{1}$ ，西村善博 $\dagger^{2}$ ，横山光宏 $\dagger^{2}$ ，奥村勝彦 ${ }^{*} \dagger^{1}$ \\ 神戸大学医学部附属病院薬剤部 $\dot{\dagger}^{1}$, 同第一内科 $\dot{\dagger}^{2}$
}

\section{Establishment of Risk-Management System for Ordering Anti-Tumor Injections}

\author{
Minoru Kumaoka $\dagger^{1}$, Yasuko Fushimi $\uparrow^{1}$, Yukihiro Arisawa $\dagger^{1}$, Kohshi Nishiguchi $\dagger^{1}$, \\ Teruhisa Matsubayashi $\uparrow^{1}$, Kyoko Nishijou $\dagger^{1}$, Toshiyuki Sakaeda $\uparrow^{1}$, Yoshihiro Nishimura $\dagger^{2}$, \\ Mitsuhiro Yokoyama $\dagger^{2}$ and Katsuhiko Okumura* ${ }^{1}$ \\ Department of Hospital Pharmacy, School of Medicine, Kobe University $\dagger^{1}$ \\ Department of Internal medicine, School of Medicine, Kobe University $\dagger^{2}$
}

$\left[\begin{array}{l}\text { Received March 16, } 2002 \\ \text { Accepted October 14, } 2002\end{array}\right]$

\begin{abstract}
Various types of protocols with several kinds of anti-tumor injections and various dosing regimens have been applied in cancer chemotherapy. The protocol is usually decided depending on the patient backgrounds including gender, age, weight and height, and type and stage of cancer. Consequently, it is well-accepted that cancer chemotherapy is one of the most risky types of pharmacotherapy. It is important but usually difficult to manage patients undergoing cancer chemotherapy. As a result, we decided to develop a cancer chemotherapy management system using computer programs. Database sets and operating programs have been developed for 10 protocols using Microsoft Access, which have enabled us to check the trade names, dose, and dosing schedule automatically. Moreover, this system indicates the recommended doses and date of administration. This system is therefore considered to be useful for the management of cancer chemotherapy patients.
\end{abstract}

Keywords — cancer chemotherapy, risk management, computer programs, automatic checking

\section{緒 言}

近年，多くの医療機関において医療過誤もしくは医療 事故が発生しており，大きな社会問題となっている。な かでも，医薬品が関与する医療過誤の割合は極めて高 く，医薬品適正使用の推進が使命である薬剤師に対する リスクマネージャーとしての期待は大きい.ところで, 癌化学療法は医療過誤が最も発生しやすい薬物療法であ るといっても過言ではない.これは, 抗悪性腫瘍剤が強 い副作用を有していること，患者によってまた癌種に よって投与量や投与間隔がまちまちであること，一般的
には複数の抗悪性腫瘍剤を併用すること, などが理由で ある．実際に抗悪性腫瘍剂の処方ミスによる死亡事故も 報道されており, 各々の医療機関において, すべての医 療従事者が協力し, 各々の医療機関の医療システムに適 した癌化学療法における医療過誤防止対策を確立するこ とが急務の課題となっている。薬剂師の立場からは, 抗 悪性腫瘍剤を適正に管理し，処方内容を監査することが 重要な作業となる。ここで，処方内容の監査とは，過量 投与もしくは過小投与のチェック，薬物相互作用の有無 のチェックにととまらず，前回投与からの投与間隔の チェックも含む.すなわち，プロトコールとの照合を意 
味する.われわれは, 経口剤と比較して, 注射薬の場合, 投与量の個人差が大きいこと，血管内に直接投与するの でとりかえしがきかないこと, を考慮し, 癌化学療法に おける医療過誤防止対策として注射処方監査支援システ ムの構築が最も重要と考えた. また, システム構築に際 して，最も効率的にかつ正確に医療過誤防止を実施する ためには，できる限り自動化することが肝要と考えた。 本稿では, 本院薬剤部で構築し実施しているコンピュー タプログラムを用いた癌化学療法に関する注射処方監査 支援システム（以下，監査支援システムと略す）を紹介 する. なお, 監査支援システムの構築に先立ち, 注射処 方監査支援シート（以下，監査支援シートと略す）を作 成，運用し，監査支援シートの長所短所を踏まえて監査 支援システムを構築したので監査支援シートについても 併せて紹介する。

\section{方法}

1. 使用ハードウェア

コンピュータ本体：FMV-BIBLO（CPU Pentium III 750
MHz, Memory 256 MB, Hard Disc 20 GB), 富士通(株) プリンタ：BJS 600, キャノン (株)

\section{2. 注射処方監査支援シートの作成と運用}

\section{1) 作成}

基本ソフトとして Windows $\mathrm{Me}^{\circledR}$ および表計算ソフト として Microsoft Excel 2000 ${ }^{\circledR}$ (Excel) を用いて監査支援 シートを作成した。今回, 運用の対象とした当院第一内 科の 10 種類の肺癌化学療法プロトコール(表 1 ) 毎に Excelのシートを設定し, 日付/時刻関数, 論理関数, 検 索/行列関数を用いて各セルを定義した。 また，患者の 身長, 体重, 体表面積ならびに初期投与日を入力するこ とにより，推奨投与量および投与スケジュールが算出さ れ，その後入力される実際の投与量と投与日が照合され るよう工夫した。

シスプラチン・イリノテカン併用プロトコールをもと に作成した監査支援シートを図 1 に示す。対象となるプ ロトコール（この場合にはシスプラチン・イリノテカン 併用プロトコール）の監査支援シートに, 病棟名, 氏

表 1. 当院第一内科肺癌化学療法の一覧

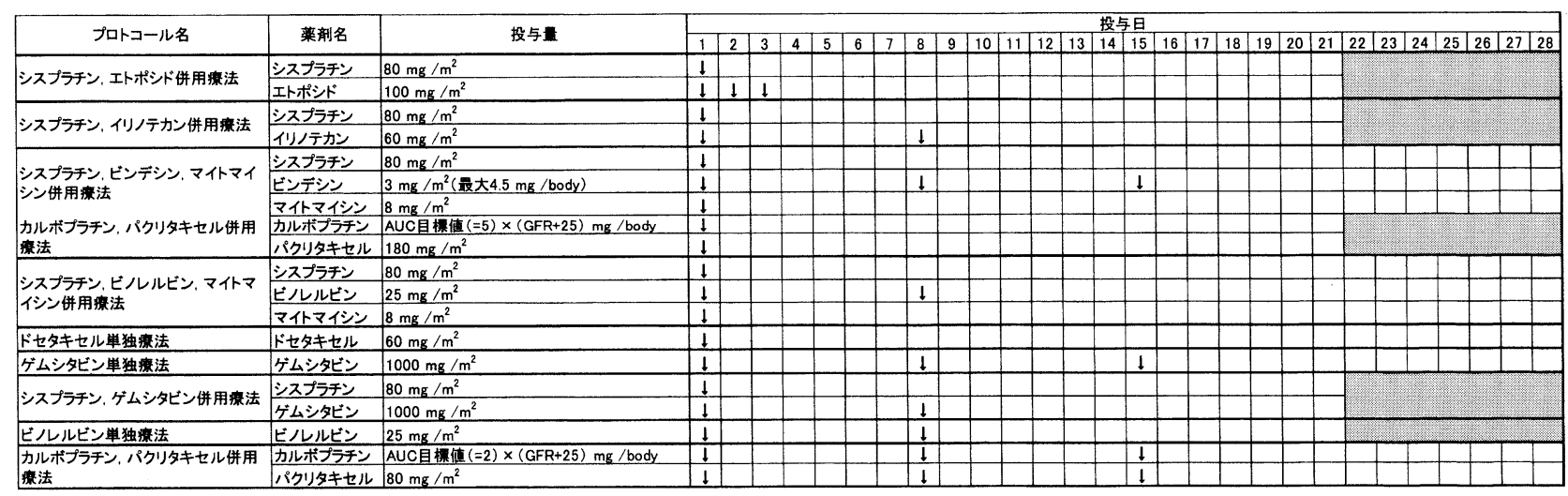

\begin{tabular}{|c|c|c|c|c|c|c|c|}
\hline \multirow{3}{*}{$\begin{array}{c}\text { 患者基本情報* } \\
\text { 病棟 8西 } \\
\text { 患者名 神戸太郎 } \\
\text { ID } 00000001\end{array}$} & & & & \multicolumn{2}{|c|}{ 第1クール } & \multicolumn{2}{|c|}{ 第2クール } \\
\hline & & & & DAY1 & DAY8 & DAY1 & DAY8 \\
\hline & & \multicolumn{2}{|r|}{$\begin{array}{r}\text { 投与日* } \\
\text { 投与予定日 }\end{array}$} & $2001 / 1 / 1$ & $\begin{array}{l}2001 / 1 / 8 \\
2001 / 1 / 8\end{array}$ & $\begin{array}{l}2001 / 1 / 21 \\
2001 / 1 / 22\end{array}$ & $2001 / 1 / 28$ \\
\hline \multirow{3}{*}{$\begin{array}{l}\text { 身長 }(\mathrm{cm}) \\
\text { 体重 }(\mathrm{kg}) \\
\text { 体表面積 }\left(\mathrm{m}^{2}\right)\end{array}$} & & 薬剂名 & 規格 & 使用量* & 使用量* & 使用畐* & 使用量* \\
\hline & 170 & イリノテカン & $40 \mathrm{mg}$ & 0.5 & 1 & 0.5 & \\
\hline & $\begin{array}{r}60 \\
1.69\end{array}$ & $\begin{array}{l}\text { イリノテカン } \\
\text { シスプラチン }\end{array}$ & $\begin{array}{l}80 \mathrm{mg} \\
50 \mathrm{mg}\end{array}$ & $\begin{array}{r}1 \\
2.6\end{array}$ & $\begin{array}{l}1 \\
0\end{array}$ & $\begin{array}{r}1 \\
2.6\end{array}$ & \\
\hline \multirow{3}{*}{\multicolumn{2}{|c|}{ 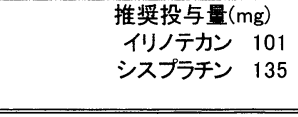 }} & 投与富合計(mg) & イリノテカン & 100 & 120 & 100 & \\
\hline & & & シスプラチン & 130 & 0 & 130 & \\
\hline & & $\begin{array}{l}\text { 前回よりの投与間隔 (日数) } \\
\text { 初回よりの投与間隔 (日数) } \\
\end{array}$ & & & $\begin{array}{l}7 \\
7 \\
\end{array}$ & $\begin{array}{l}13 \\
20 \\
\end{array}$ & \\
\hline \multirow{2}{*}{\multicolumn{2}{|c|}{ 照合結果 }} & 投与間隔 & & & 適正 & 不適 & \\
\hline & & 投与量 & $\begin{array}{l}\text { イリノテカン } \\
\text { シスプラチン }\end{array}$ & 適正 & 過量 & 適正 & \\
\hline
\end{tabular}

*: 患者ごとに入カが必要な項目

医師に照会医師に照会

図 1. 監査支援シート 
68

名, ID 番号, 身長, 体重, 体表面積を入力すると, 自 動的に, 推奨投与量が算出され投与スケジュールが表示 される，次に，薬剤部に出力された登録患者の注射薬処 方せんを参考に, 薬剤の投与量 (本数) と投与日を手入 力することで，これらの適否を照合した．実際の投与量 が推奨投与量を超過している場合には，「超過」ならび に「医師に照会」というエラーが表示される。また，実 際の投与日と投与スケジュールとの照合を行い, 投与間 隔が短い場合には「不適」ならびに「医師に照会」とい うエラーコメントが表示される。

癌化学療法では, 一般的に, 投与が数回繰り返さ れ，1クールが数週間におよび, 数クールが繰り返され る. 今回の対象プロトコールに拈ても，1クールが 3 週間あるいは 4 週間におよび，これらが繰り返される。 また，反応が悪い場合にはプロトコールの変更が行われ る場合がある。そこで，患者の履歴を知ることが出来る ように, 対象患者の ID 番号をもとに過去に受けた癌化 学療法プロトコールが容易に検索できるよう図 2 に示す プロトコール検索シートを作成した. さらに，検索結果 をもとに監査支援シートヘリンクする機能を付与した。

\section{2 ）運用}

2000年 5 月～2001年 3 月の期間に当院第一内科にて肺 癌化学療法が実施される患者を対象とした。また，あら かじめ, 解析に必要な患者の基本情報は医師や病棟担当 薬剂師より入手した. 薬剂部に出力される対象患者の注 射薬処方也んから監査支援シートへ薬剤名および使用量 を手入力することにより，投与量ならびに投与日がプロ トコールと合致しているのか否かを照合した.

\section{3. 注射処方監査支援システムの構築と運用}

\section{1) 構築}

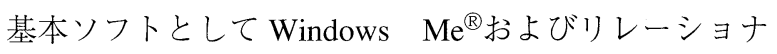
ル型データベースソフトとして Microsoft Access $2000^{\circledR}$ (Access) を用いて監査支援システムを構築した（図３）. すなわち，4 項目のテーブル (患者情報, 投薬情報, 薬 品マスター, 治療法マスター), 各プロトコールにつき 3 項目のクエリー（解析, 照合, 予定)により構成し た。また，操作性の向上のため各プロトコールにつき 3 項目のフォーム（入力，照合結果，投与予定）およびす ベてのプロトコールに共通する 2 項目のフォーム（メイ

\begin{tabular}{|c|c|c|}
\hline これまでに行った肺癌化学療法 & 入力画面へ & 投与期間 \\
\hline \multirow{8}{*}{$\begin{array}{l}\text { シスプラチン+エトポシド併用療法 } \\
\text { シスプラチン+イリノテカン併用療法 }\end{array}$} & シスプラチン+エトポシド併用療法へ & 1クール3週 \\
\hline & シスプラチン+イリノテカン併用療法へ & 1クール3週 \\
\hline & シスプラチン+ビルルルビン+マイトマイシン併用療法へ & 1クール4週 \\
\hline & ドセタキセル単独療法へ & 1クール4週 \\
\hline & ゲムシタビン単独療法へ & 1クール4週 \\
\hline & シスプラチン+ゲムシタビン併用療法へ & 1クール3週 \\
\hline & ビノレルビン単独療法へ & 1クール3週 \\
\hline & カルボプラチン+パクリタキセル併用療法へ & 1クール4週 \\
\hline
\end{tabular}

困 2.プロトコール検索シート

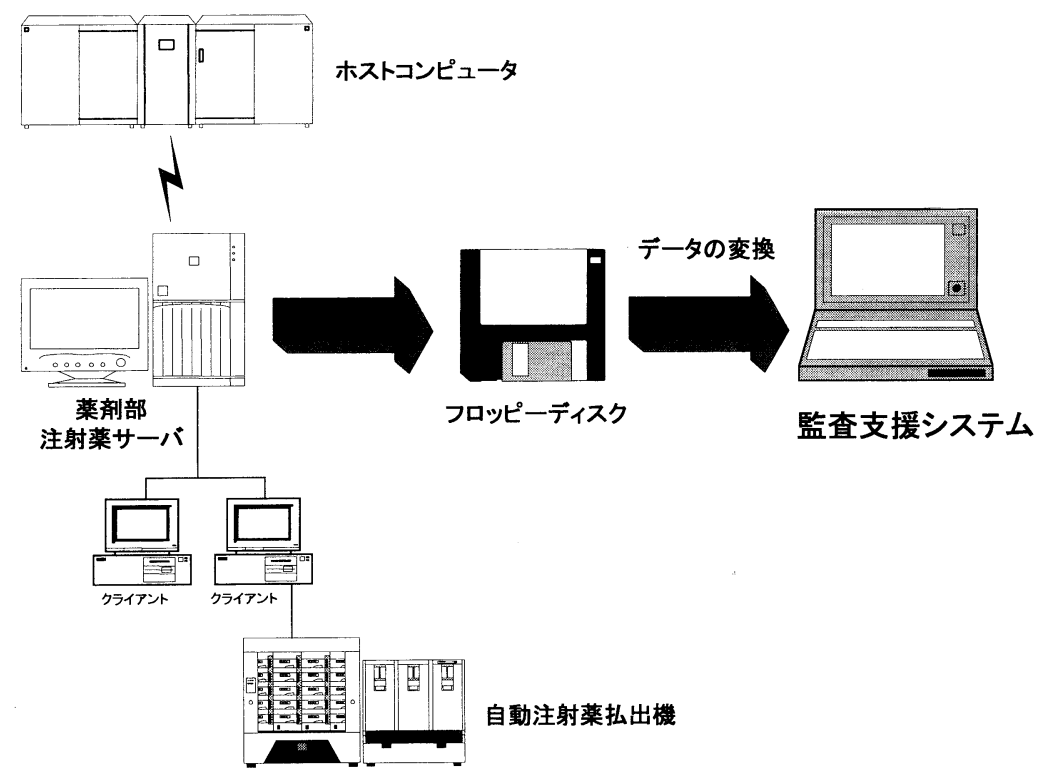

図 3. 処方オーダデータの流れ 
ン，患者登録）を作成した。さらに，日付/時刻関数， プログラムフローを利用し，事前に患者の身長，体重， 体表面積を入力することにより対象プロトコール毎の推 奨投与量および投与予定日を算出し，実際の投与量，投 与日と照合するようにデータベースを構築した。なお， 図 3 に示したように，ホストコンピュータにオーダ入力 された各患者の抗悪性腫瘍薬処方情報は, 薬剂部注射薬 サーバを介してフロッピーディスクに抽出した後, デー タベースへ直接インポートできるよう工夫した。

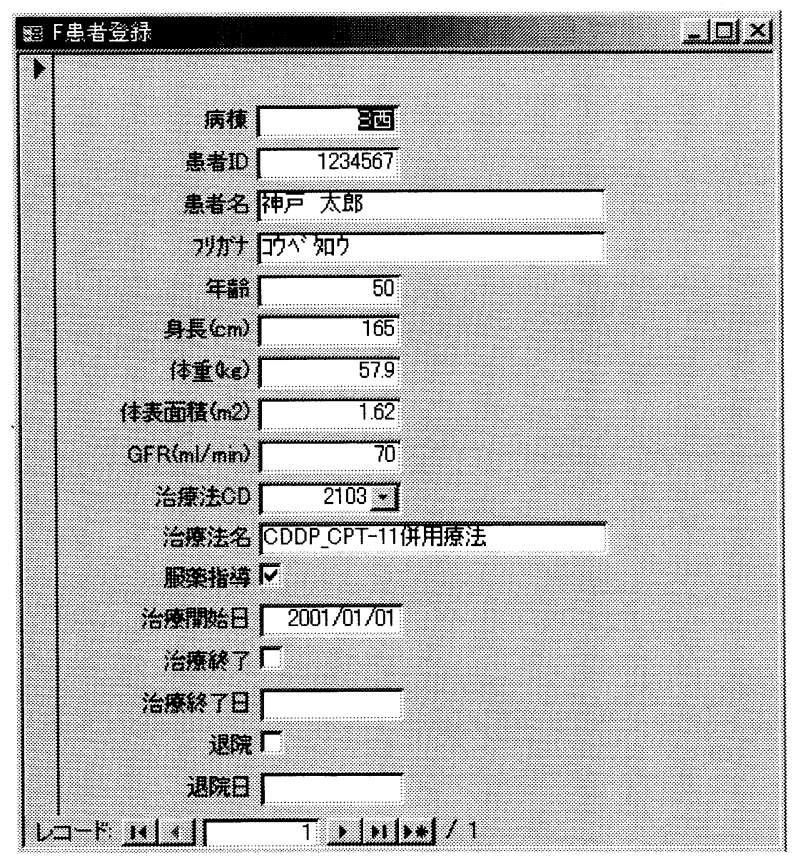

図 4. 患者登録フォーム
シスプラチン・イリノテカン併用プロトコールを例と して監査支援システムを説明する。まず，患者の基本情 報として病棟名, 氏名, ID番号, 身長, 体重, 体表面 積および治療を受けるプロトコール名を図 4 に示す“患 者登録フォーム”より患者情報テーブルに入力する。

ホストコンピュータにオーダ入力された各患者の抗悪 性腫瘍薬処方情報を，薬剤部注射薬サーバを介してフ ロッピーディスクに抽出した後, データベースの投薬情 報テーブルにインポートする。ここで図 5 に示す “入力 フォーム”よりクール番号およびDAY 番号をプルダウ ンメニューより選択入力した後, 入力項目のうち照合に 必要な情報のみ抽出し解析を行う解析ボタンを押すこと で薬剂の名称，投与日，投与量の適否を照合する。この 照合結果は結果ボタンを押すことで表示され (図6), さらに予定ボタンを押すことで今後の投与予定を表示さ れる(図7).また，診療科から提出されたプロトコー ルとはまったく別のプロトコールで治療が行われる場合 に備えて，抗悪性腫瘍剂の投薬歴のみの管理も可能なよ うに設定した。

なお，手書き処方せんにより払出した抗悪性腫瘍剤は 入力フォームから投薬情報を手入力するが, データベー スへ手入力する祭の誤入力を防ぐため, 各プロトコール に規定されていない投薬情報を入力しようとした際には エラーコメントを表示し入力ができないよう, 入力内容 の制限をプロトコール毎に設定した。

2 ) 運用

2001年 1 月～ 5 月の期間に当院第一内科にて肺癌化学 療法が実施される患者を対象とした。またあらかじめ,

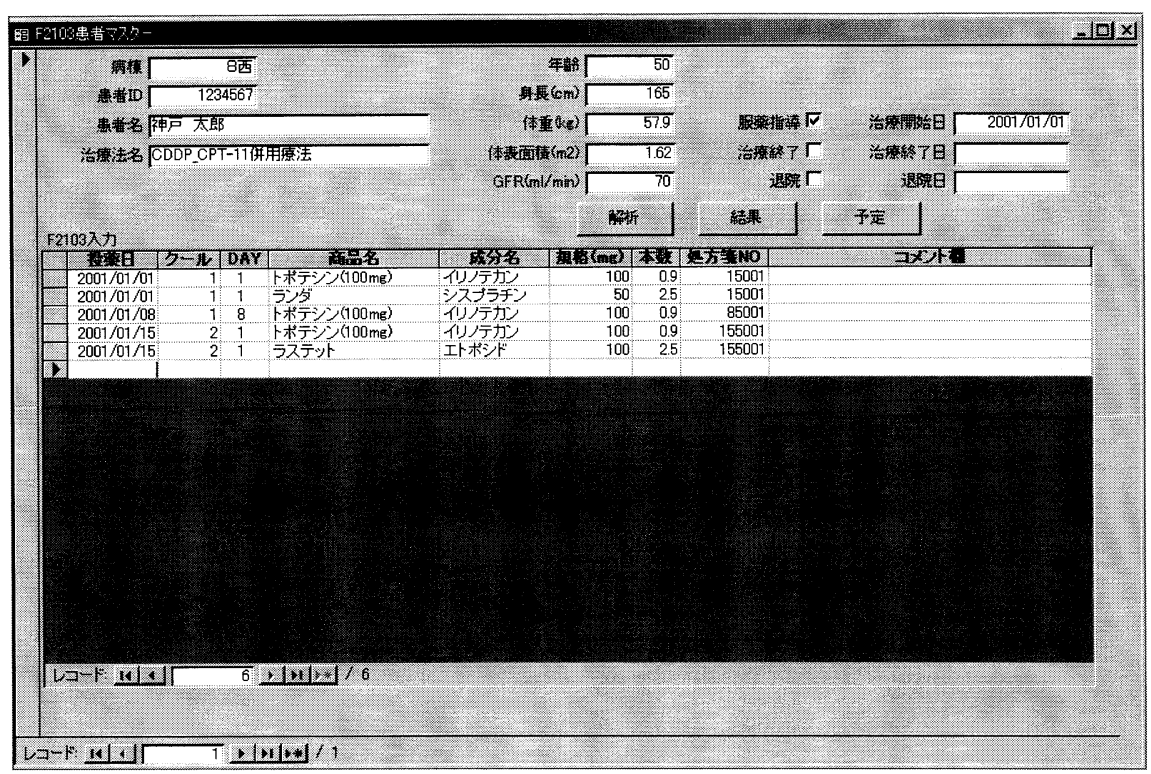

図 5. 入力フォーム 


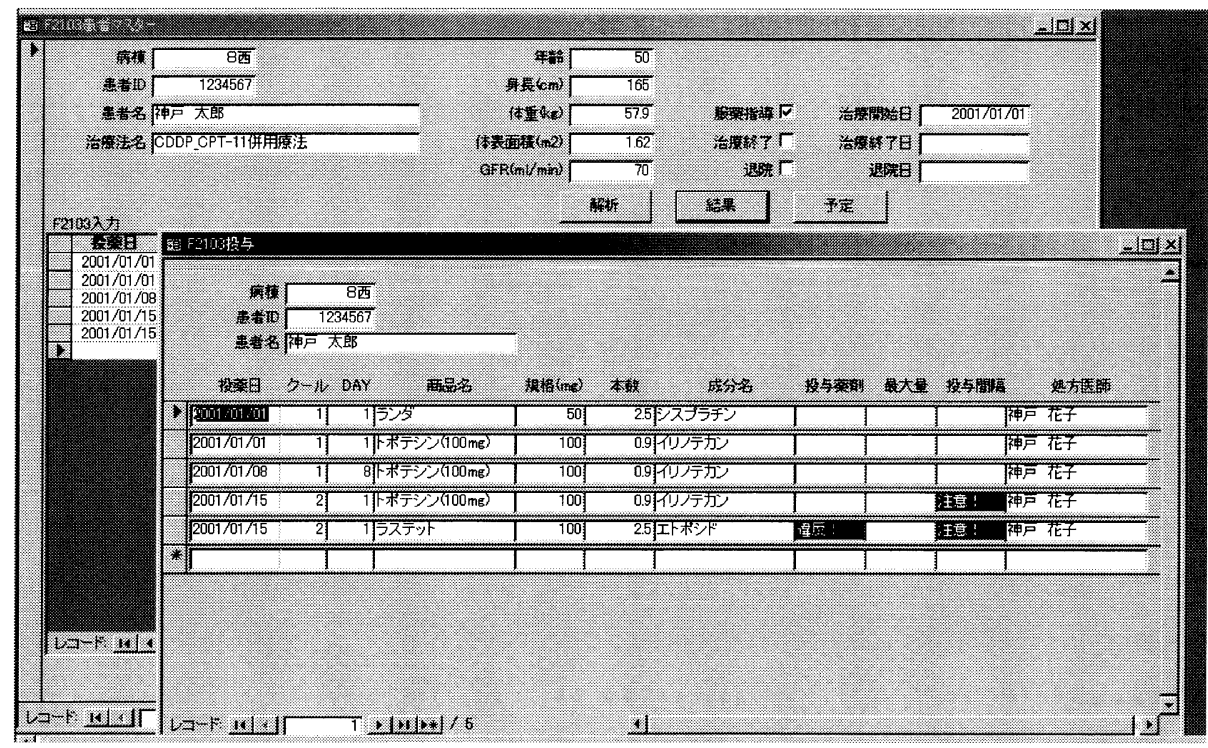

図 6. 照合結果

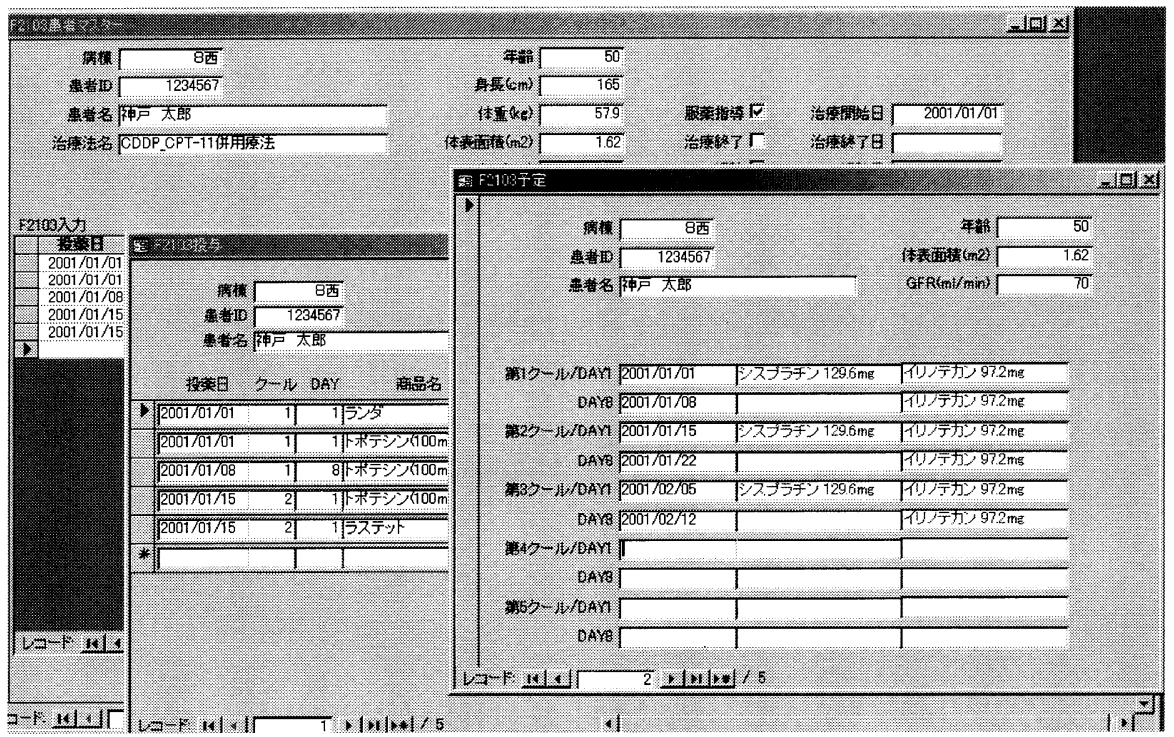

図 7. 投与予定表

解析に必要な身長, 体重, 体表面積等の患者基本情報や 癌化学療法プロトコールは医師や病棟担当薬剤師より入 手した。薬剤部注射薬サーバを介して抽出した対象患者 の注射薬処方情報を監査支援システムのデータベースに インポートし，薬剤名称，投与量ならびに投与日が，す でに登録されているプロトコールと合致するのか否かに ついて照合した。

\section{結果}

われわれは，コンピュータプログラムを用いた癌化学 療法に関する監査支援システムの構築を目的として，ま
ず，比較的容易に作成できる監査支援シートを作成し た。しかしながら，いくつかの問題点が明らかとなった ので，それらを踏まえて監査支援システムを構築した。 これらについての検討結果を以下に示す.

\section{1. 監査支援シートの運用}

運用期間中, 肺癌化学療法を実施した症例は38例であ り，このうち監査支援シートを適用できた症例は 32 症例 であった。適用できなかった例として，表 2 に示すよう に投与スケジュールが提出されたプロトコールとまった く異なっていたものがあげられた。なお，監査支援シー 
表 2. 提出されたプロトコールになかった症例の投与スケジュール

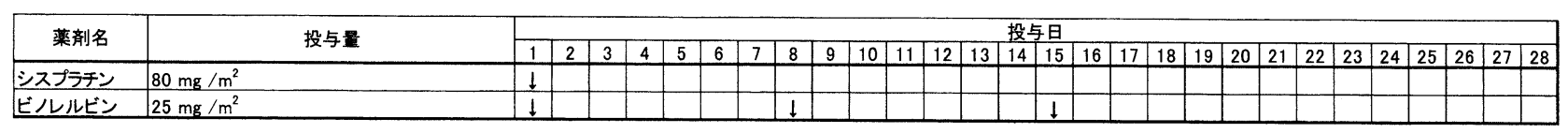

トが適応可能であった症例において，疑義照会により薬 剤の投与量・投与日の変更に至った症例はなかった。

\section{2. 監查支援シートの運用上の問題点}

運用期間中，使用されたプロトコール数は 10 種類であ り，最大で 3 クール（12週間）にわたり繰り返し投与が 実施された。コンピュータプログラムを使用しない通常 の方法での処方監査では 1 処方あたり平均 7 分かかって いたが，監査支援シートを利用する方法では 1 処方あた り4.5分であり, 効率的な処方監査が実施できたが，そ れでも, 多大な労力が必要であった。また, 監査支援シー トへの入力は処方せんをもとにした手入力であることか ら, 䛊入力が懸念された.

また，患者の病態等によりプロトコール上の投与薬物 であるシスプラチンから類薬のカルボプラチンに適宜変 更するなど，本来のプロトコールに若干の変更を加えた 亜種のプロトコールに基づいて癌化学療法を行う症例が あったが，このような場合監査支援シートにおいては新 規プロトコールとして別途作成する必要があり柔軟に対 応することは難しく, 同一プロトコールによる一連の治 療として一元的に管理することが不可能であった。

このように，監査支援シートの運用により，抗悪性腫 瘍剤の払出段階において癌化学療法プロトコールに基づ いた処方監査とエラーの検出が容易になることが示され たが，運用上や操作上の改善すべき課題が残された。そ こで, 監査支援シートの操作性と機能を改善する目的 で，以下に示す監査支援システムを構築した。

\section{3. 監査支援システムの運用}

運用期間中, 肺癌化学療法を実施した症例は20例であ り，全症例において監査支援システムを適応した。監査 支援システムにより，疑義照会により薬剤の投与量・投 与日の変更に至った症例は図 8 に示す 2 症例であった。

運用期間中, 使用されたプロトコールは 7 種類であ り，最大で 3 クール（12週間）にわたり繰り返し投与が 実施されたが，監査支援システムを運用することにより 1 処方あたり平均 2.1 分で処方監査を行うことが可能と なり, 注射薬調剂業務の負担を増加することなく簡便か つ迅速に照合することが可能であった。また監査支援シ ステムを運用することにより各プロトコールにおける投 与量および投与日に加え, 投与される抗悪性腫瘍剤の名

\section{ビルルビン単独療法 \\ 1クール3週, DAY1. $25 \mathrm{mg} / \mathrm{m}^{2}$}

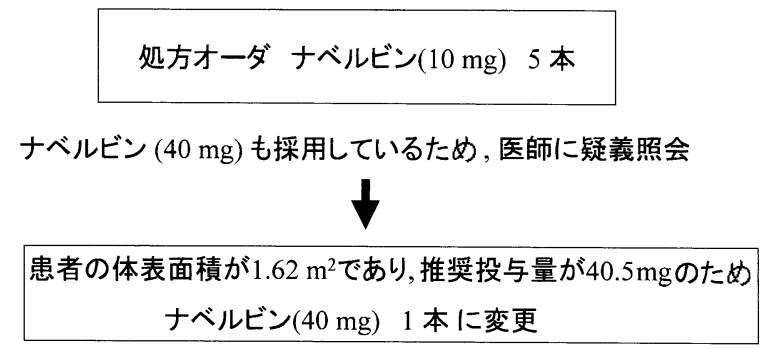

図 8a. 疑義照会により投与量が変更となった 症例 (1)

\section{カルボプラチン, パクリタキセル併用療法 \\ 1クール3週, DAY1. C CBDCA AUC目標値 $(=5) \times(\mathrm{GFR}+25)(\mathrm{mg} / \mathrm{body})$ TXL $\quad 180 \mathrm{mg} / \mathrm{m}^{2}$}
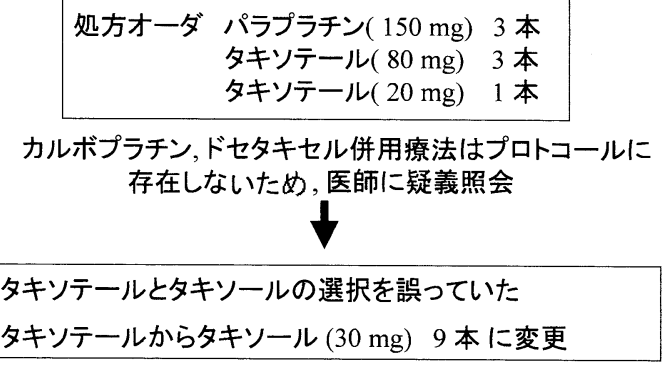

図 8b．疑義照会により投与量が変更となった 症例 (2)

称も照合することが可能となった.さらに, 監査支援シー トでは行えなかった患者毎の抗覀性腫瘍剤の投与量・投 与日の予定を一覧表にすることが可能となり, 癌化学療 法の治療管理が一層容易となった。このように監査支援 システムの運用により，抗悪性腫瘍剤の用法用量の妥当 性や患者個々の治療状況を迅速かつ正確に把握し, 抗悪 性腫瘍剂の払出段階において癌化学療法プロトコールに 基づいた処方監査とエラーの検出が可能となった.

\section{考察}

医療過誤の中でも投薬に関する過誤が最も多いものの 一つとしてあげられている1). 投薬に関する代表的なエ ラーとしては「投与量の誤り」,「誤った薬剤の選択」,「投 


\section{2}

与時間の誤り」があげられ, 癌化学療法においてはいず れも患者に極めて重篤な結果を与える2).この点, 今回 われわれが構築した監査支援システムは, 薬剤名称, 投 与間隔も含めたプロトコールとの照合とエラーの検出を 迅速, 簡便かつ正確に行えるものであり, 医療過誤防止 にとって有用であると考えられた。

投薬に関する過誤には，オーダリングシステムにおい て処方を行う際に類似した名称の薬物を䛊って選択する ことにより引き起こされた事例も報告されている。この ため，これらの薬剤には警告ウィンドウを表示したり， 成分名による名称の登録をしたりするなど，多くの施設 で類似した名称を持つ医薬品に対するさまざまな方策が 施されている ${ }^{3,4)}$. 当院においても処方入力時のケアレ スミスによる薬剤選択間違いを防止するため, オーダ上 に類似する薬剤の名称が存在する場合には一方を薬剤 名, 他方を一般名十薬剂名による登録を行っている。力 ルボプラチン, パクリタキセル併用療法に招いてよく似 た名前の薬剂（ドセタキセル）が䛊って処方された症例 (図 8b) に打いても，“夕キソ”と入力した際に“タキ ソテール”ならびに“パクリタキセル (タキソール)”と 表示されていたにも関わらず，医師は思い込みにより夕 キソテールを処方して抢り，疑義照会で指摘するまで, その過ちに気が付いていなかった，その指示量は添付文 書上の最大投与量の約 2.5 倍にも及んでいた (図 $8 \mathrm{~b}$ ). このように思い込みにより誤った薬剤がオーダされる場 合においては，名称が類似した紛らわしい医薬品に対す る方策だけでは医療過䛊の回避は難しい. しかしなが ら, 今回構築した監査支援システムを併用して活用する ことによりプロトコールに基づいた薬品名称，投与量， 投薬日の管理が可能となり, 薬剂の払出段階において処 方上のエラーを的確に検出し, 医療過誤を回避すること が可能となるものと考えられた。

監査支援システムにおいて，抗悪性腫瘍剂の投与量は 患者個々の身長, 体重, 体表面積から厳密に計算される ため, 医師がオーダで処方入力する際に払出単位での処 方入力を行う症例ではすべての症例で投与量が過量であ ると認識された。過量であると認識された症例において は実施された投与量を確認する必要があったため，才ー ダ入力は必ず実施量で行う必要があるという課題も残さ れた。

さらに，監査支援シートならびに監査支援システムの 運用期間中に，診療科から提出されたプロトコールとは まったく異なる抗悪性腫瘍剂の組み合わせを使用した症
例もあった，表 2 に示す症例においてはカルボプラチン とビノレルビンを併用するプロトコールがなかったた め, 病棟担当薬剮師を通じて医師に疑義照会を行った。 通常のプロトコールではシスプラチン，ビノレルビン， マイトマイシンの 3 剂併用療法（1クール4週間）で あったが，当該患者においては腎機能が低下しているた め, シスプラチンからカルボプラチンに変更することお よび副作用軽減のためマイトマイシンは使用せず，ビノ レルビンをDAY 1，8，15に使用するという情報を病 棟担当薬剤師より得た。この薬剤の組み合わせは本来プ ロトコールには示されていないが，上記の理由から問題 がないことを確認した，個々の症例の治療において，抗 覀性腫瘍薬の選択は薬剤の作用機序からの類推や過去の 経験的事実に基づいて，それぞれに有効な薬物を併用 し，かつ副作用の低減を計るために複雑に変更すること もあるのが実状である。プロトコールにない症例の治療 においてはコンピュータによる監査支援の対象とはなら ないため，あらかじめ薬剤部に連絡が必要となる。この ように医師, 病棟担当薬剤師との緊密な連携が癌化学療 法に拈りるリスクマネージメントに拈いて重要となる.

以上，コンピュータによる監査支援システムを構築す ることにより, 迅速かつ簡便に癌化学療法の処方監査を 行い，的確にエラーを検出することが可能となった。ま たコンピュータによる監査支援システムの構築に加えて 病棟活動と緊密に連携することにより, 抗悪性腫瘍剂の 使用に揸いて，リスクマネージメントに大きな寄与を果 たすことが可能となった。今後は種々の癌化学療法に対 しても監査支援システムを運用するとともに完全に自動 化し，広く医療過誤の防止に努めていきたい.

\section{引用文献}

1）厚生科学研究「医療のリスクマネージメント構築 に関する研究班」報告（主任研究者：川村治 子), 2000年 6 月 26 日.

2) L.L. Leape, D.W. Bates, D.J. Cullen, J. Cooper, H.J. Demonaco, T. Gallivan, R. Hallisey, J. Ives, N. Laird, G. Laffel, R. Nemeskal, L.A. Petersen, K. Porter, D. Servi, B.F. Shea, S.D. Small, B.J. Sweitzer, B.T. Thompson, M.V. Vliet, Systems analysis of adverse drug events, JAMA, 274, 35-43(1995).

3）古川裕之, 分校久志, 宮本謙一, 医療事故防止対 策における薬剤部の役割, 月刊薬事, 42, 61-67 (2000).

4) 谷川原祐介, 中山和彦, 河村俊一, 間違えやすい 医薬品，月刊薬事，42，81-86(2000). 